\title{
Preliminary studies on copepod infestation of the garfish (Ablennes hians) landed at Elmina harbour, Ghana
}

\author{
E.A. OBODAI ${ }^{1 *}$, J. AGGREY-FYNN $^{1}$, R. AGBEMAFLE ${ }^{1}$, A.A. NIMAKO ${ }^{1}$ and \\ M.D. NUTOR ${ }^{1}$
}

${ }^{I}$ Department of Fisheries and Aquatic Sciences, University of Cape Coast, Cape Coast, Ghana.

${ }^{*}$ Corresponding author; E-mail: obodai254@yahoo.com

\begin{abstract}
A study was conducted to investigate the degree and effect of copepod infestation of the buccal cavity of the gar fish landed at the Elmina harbour in Central Region of Ghana, on some body parameters and sex ratio of the fish. The results indicate that the degree of infestation was significantly high (64.19\%) compared to non-infestation (35.81\%). The highest infestation (21.30\%) occurred in animals with standard length class interval of 75.0-79.9 $\mathrm{cm}$ and the least (3.40\%) was in 80.0-84.9 $\mathrm{cm}$. The highest infestation was recorded in the breadth class interval of $60.0-6.9 \mathrm{~cm}$. The least $(5.70 \%)$ was in $5.0-5.9 \mathrm{~cm}$. The mean standard length of the infested animal was $74.45 \pm 6.50 \mathrm{~cm}$, while that of the non-infested was slightly higher $(77.45 \pm 6.36 \mathrm{~cm})$. Mean body depth of the infested was slightly lower $(6.94 \pm 0.86 \mathrm{~cm})$ than that of the non-infested $(7.08 \pm 0.94$ $\mathrm{cm}$ ). Mean condition indices of infested and non-infested garfishes were similar (about $1.42 \times 10^{-1}$ ) for each group. Sex ratios of infested (1:1.02) and non-infested (1:1.36) did not differ significantly. Similarly, the standard length-gill length and gill volume of infested and non-infested garfishes were close to each other, but slightly more positive for the non-infested animals. Finally, the results of biochemical composition indicate that the various components did not differ significantly between infested and non-infested. Protein content was high (20.30\%), but fat content was rather low $(8.50 \%)$ for both infested and non-infested garfishes. It is concluded that infestation had no significantly negative effect on the garfish.
\end{abstract}

(C) 2011 International Formulae Group. All rights reserved.

Keywords: Copepod, garfish, Elmina, condition indices, infestation, buccal cavity.

\section{INTRODUCTION}

The garfish (Ablennes hians L. 1758), belonging to the Family Belonidae, is one of the marine fishes of high food value landed at the Elmina harbour. The fish has slender, body which is relatively flexible. The body is tubular, elongated and has a similar depth along the entire length. The median fins (dorsal and ventral) are placed well back close to the caudal fin. The body is covered with rhomboidal ganoid scales. The fish has elongated snout with a single row of long sharp teeth. The teeth and the snout enable the garfish thrash its head to capture and hold its preys (Paulson and Hatch, 2001).

The species is slow growing with relatively long life span. The male rarely attains 11 years, but female lives up to 22 years (Hatch, 2003). The garfish begins life by feeding on small crustaceans such as copepods and aquatic insects; but it quickly switches over to feeding primarily on fish. 
The species feeds both day and night, but it is more active as night feeder. Although there are many studies on marine parasites, those that deal with endoparasites of marine fishes are limited (Kennedy and Williams, 1989). The rate of parasite infestation varies from locality to locality.

Copepod infestation of the buccal cavity of the garfish and its effect have not been documented scientifically in Ghana. Hence the objectives of this study were to investigate the degree of infestation and its possible effects on some body parameters and the biochemical composition of the garfish landed at the Elmina harbour in Central Region of Ghana.

\section{MATERIALS AND METHODS}

Study area

The study was carried out on fish landings at the Elmina fishing harbour, which is located between latitudes $5^{\circ}$ and $5^{\circ} 30^{1} \mathrm{~N}$ and longitudes $1^{\circ} 15^{1}$ and $1^{\circ} 30^{1} \mathrm{~W}$. The town is about $10 \mathrm{~km}$ west of the University of Cape Coast (Figure 1). The study covered a period of three years (2006, 2007 and 2008), due to the seasonal nature of the garfish fish fishery.

\section{Examination of buccal cavity}

The fish specimens for the experiment were procured from the fishermen and/or the fishmongers. The beaks were held apart, the tongue lifted and the buccal cavity was examined with the aid of a pair of forceps for the presence or absence of the copepod.

\section{Measurement of standard length and breadth}

The standard length of the garfish was taken with the aid of a tape measure placed along the fish from the tip of the beaks (snout) to the base of the caudal fin. The breadth was measured from the dorsal line to the ventral line at its deepest portion.

\section{Determination of condition index}

The weight of each specimen was obtained (to the nearest 0.1 of a gramme by using a weighing scale. The total length of each specimen was also measured with a tape measure. The condition index (C.I.) of each specimen was calculated by using the fornula: C.I. $=\frac{\mathrm{W} \times 100}{\mathrm{~L}^{3}}$

$$
\mathrm{L}^{3}
$$

Where $\mathrm{W}=$ weight $(\mathrm{g})$ and $\mathrm{L}=$ total length (cm) (Bagenal, 1978).

\section{Sex ratio}

The sex of each specimen was ascertained by examining its gonad: creamy gonads for a male and a shade of purple or presence of eggs for a female.

\section{Determination of gill length and volume}

The gill of each specimen was carefully removed with the aid of pairs of scissors and forceps. A piece of thread used to describe the curvature was then stretched against a meter rule to obtain the actual length of the gill to the nearest 0.1 of a centimeter. The volume of the gill was obtained by the displacement method, using a $500 \mathrm{ml}$ measuring cylinder, containing a known volume of water.

\section{Biochemical composition \\ Collection, preservation and preparation of samples for analysis}

Fresh samples of infested and noninfested garfishes, bought from Elmina, were each placed in a separate transparent polyethylene bag, labelled and put in an ice chest containing pieces of ice blocks. The samples were then sent to the Food Research Institute in Accra for analysis. Samples were removed from the ice chest and allowed to thaw completely. The head, tail, scales, skin and fins were carefully removed. Fillet was scrapped into a mortar using a sharp knife. The fillet was mashed until a homogeneous mixture was obtained. Each mixture was stored in a labelled container and kept in a refrigerator to prevent spoilage.

The portion for determination of proximate analysis, on dry matter basis, (DMB) was oven - dried at $50{ }^{\circ} \mathrm{C}$ over night and used for the determination of moisture, 
protein, fat, carbohydrate and ash contents, using AOAC (1990).

\section{Moisture dertermination}

In the preparation porcelain dishes were washed and rinsed with distilled water and dried in an oven for about twenty minutes. Well mixed fish sample of about $3.093 \mathrm{~g}$ $3.199 \mathrm{~g}$ was accurately weighed in pre-heated porcelain dishes. The samples were dried with the dishes for four hours in an oven provided with open ventilation and maintained at 105 ${ }^{0} \mathrm{C}$ to obtain constant weight. Each dish was removed and allowed to cool in a desiccator and weighed. The difference between the wet and dry weights gave the moisture content.

Percentage moisture content (Moisture \%) was calculated as:

Moisture content $(\%)=\left(\left(\mathrm{W}_{\mathrm{f}}-\mathrm{W}_{\mathrm{d}}\right) / \mathrm{W}_{\mathrm{f}}\right) \times 100$

in which:

$\mathrm{W}_{\mathrm{f}}=$ weight of dish + fresh sample

$\mathrm{W}_{\mathrm{d}}=$ weight of dish + dried sample

\section{Protein content}

Protein content was determined by estimating the total nitrogen, using the macroKjeldahl method and multiplying the value by 6.25 .

\section{Fat}

Fat was extracted by the continuous Soxhlet extraction method, while the ash content was determined by igniting $5 \mathrm{~g}$ of the dry meat to ash in a muffle furnace at $550{ }^{\circ} \mathrm{C}$.

\section{Carbohydrate}

Carbohydrate was obtained by subtraction of protein, fat and ash values from 100 .

\section{RESULTS}

Degree of copepod infestation of buccal cavity among garfish population

In all a total of 296 garfishes were examined for the presence or otherwise of the copepod. Of this number, $190(64.19 \%)$ were infested, while only $106(35.81 \%)$ were not. Thus the level of copepod infestation (64.19\%) of the buccal cavity of the garfish landed at the Elmina harbour was statistically significant (Table 1a).

The results in Table 1a also indicate that the size class with the highest infestation was $75.0-79.9 \mathrm{~cm}$, which had $21.3 \%$, followed by $70.0-74.9 \mathrm{~cm}$ with $18.2 \%$. The class range of $80.0-84.9 \mathrm{~cm}$ had the least infestation (3.4\%). The class sizes of 60.0-64.9 cm, 85.0$89.9 \mathrm{~cm}$ and $65.0-69.9 \mathrm{~cm}$, scored $5.4 \%, 6.1 \%$ and $9.8 \%$, respectively.

The breadth (depth) of garfish with the highest infestation was in the range of 6.0-6.9 $\mathrm{cm}(31.4 \%)$ followed by $7.0-7.9 \mathrm{~cm}(17.9 \%)$, 8.0-8.9 $\mathrm{cm}(9.8 \%)$ and 5.0-5.9 $\mathrm{cm}$ which had the least infestation of $5.7 \%$ (Table 1b). Therefore the copepod infestation was heaviest among garfishes within standard length ranges of 70.0-70.79.9 $\mathrm{cm}(39.5 \%)$ and body depth range of $6.0-7.9 \mathrm{~cm}(49.3 \%)$.

The mean standard length of the infested specimens was $74.45 \mathrm{~cm}( \pm 6.58$ S.E), while that of the non-infested ones was $77.45 \mathrm{~cm}( \pm 6.36)$; the mean body depths of the infested and non-infested garfishes were $6.94 \mathrm{~cm}( \pm 0.86 \mathrm{~S} . \mathrm{E})$ and $7.08 \mathrm{~cm}( \pm 0.94$ S.E), respectively. The differences in these body parameters between infested and noninfested garfishes were not significant (Tables $1 \mathrm{a}$ and $\mathrm{b})$.

\section{Condition indices of infested and non- infested garfishes}

The condition indices of the infested garfishes ranged from $1.10 \times 10^{-1}$ in the second week of January to $1.69 \times 10^{-1}$ in February with a mean of $1.417 \times 10^{-1}$. Those of the noninfested specimens ranged from $1.20 \times 10^{-1}$ in January to $1.68 \times 10^{-1}$ and the mean was $1.424 \times 10^{-1}$ hence there was no significant difference between the condition indices of the infested and non-infested garfishes (Figure 2).

\section{Sex ratio of infested and non-infested garfishes}

Table 2 indicates that the overall sex ratio of the infested fishes (1:1.02) was slightly in favour of females. Similarly, that of the non-infested garfishes also showed slight female dominance $(1: 1.36)$. However, the differences in either case were not statistically significant. Infestation tended to draw the sex ratio closer to the optimum level of $1: 1$. 


\section{Standard length-gill parameters of infested and non-infested garfishes}

There was no significant difference in the standard length-gill length of infested and non-infested garfishes studied. The correlation coefficient (R) were $41.8 \%$ infested and $43.7 \%$ for non-infested. Similarly, the relationships between standard length and gill volume of infested and non-infested garfishes were 11.1048 and 11.2485 which did not differ significantly, as shown in Figure 3, with
Gill volume $=-11.1038+0.224663$ Standard length.

Biochemical composition of infested and non-infested garfish

The results in Table 3 indicate only minimal differences in the components determined. In all, except carbohydrate, the components are slightly higher for the noninfested than the infested garfishes. However, the differences in these components between the infested and the non-infested individuals were not significant.

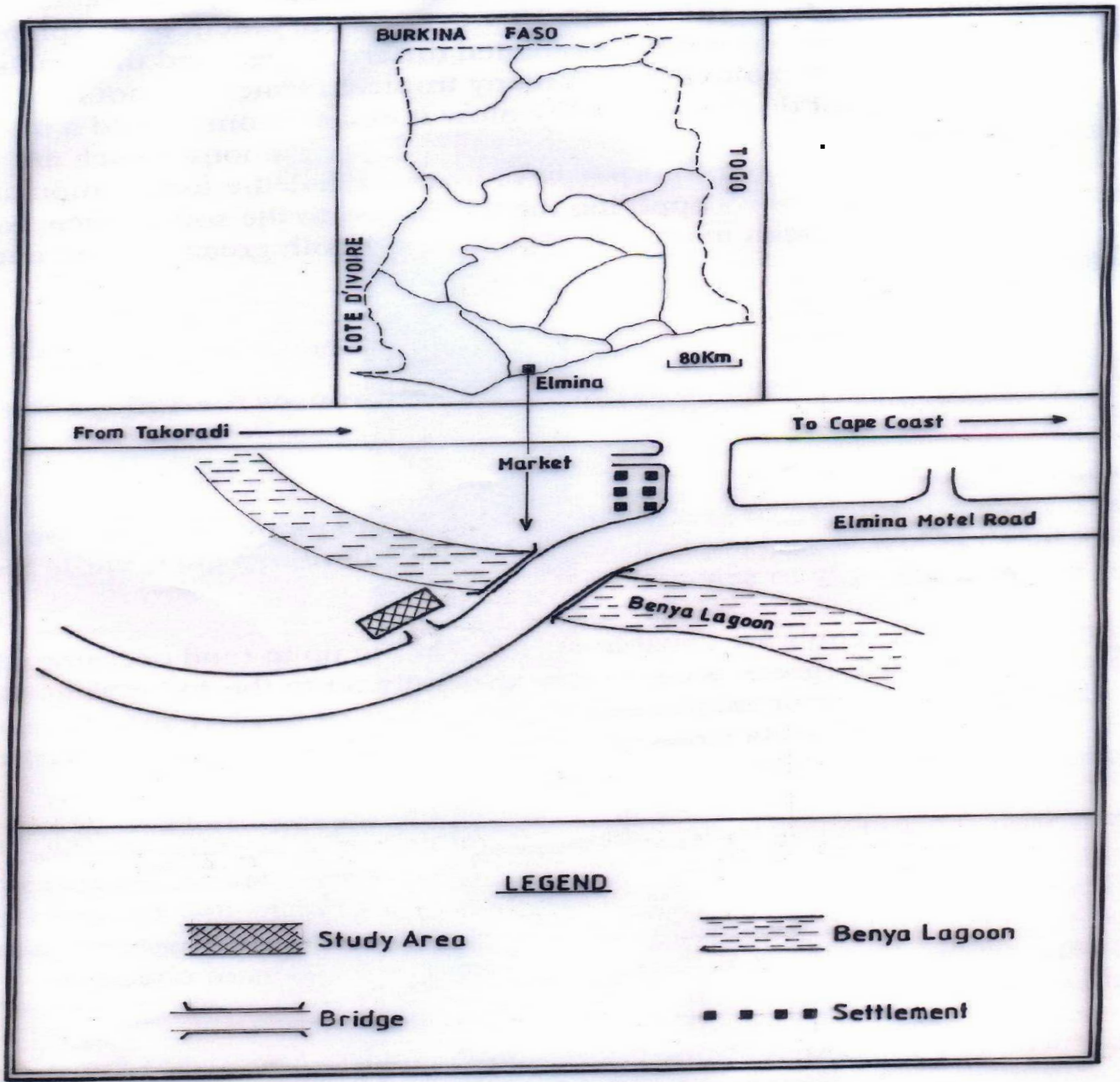

Figure 1: A sketch map showing the study area (Elmina Harbour). 


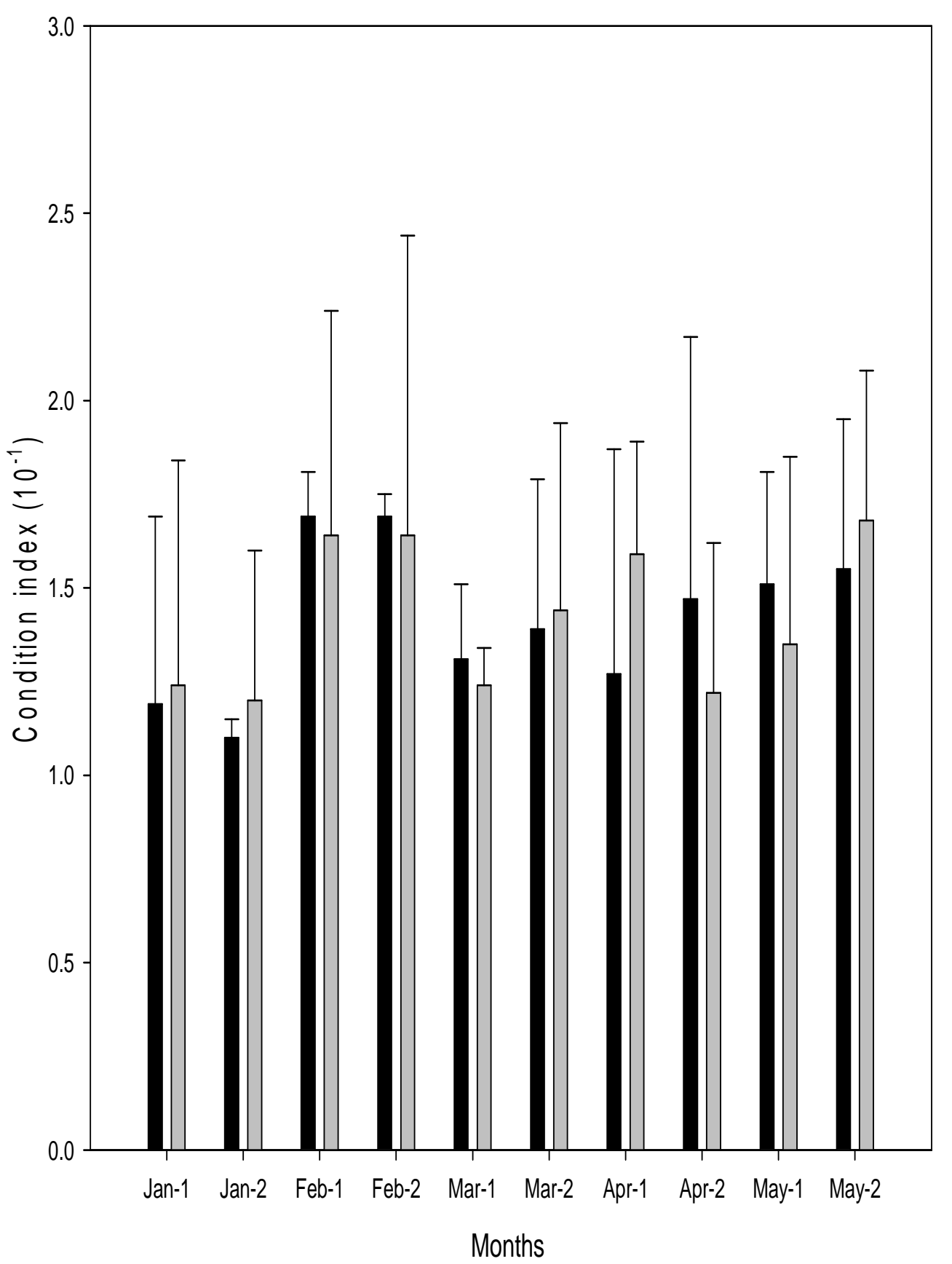

Figure 2: Condition index of infested dark and non-infested light garfish landed at the Elmina harbour.

1 means first week of the month; 2 means second week of the month. Vertical lines are standard error bars. 

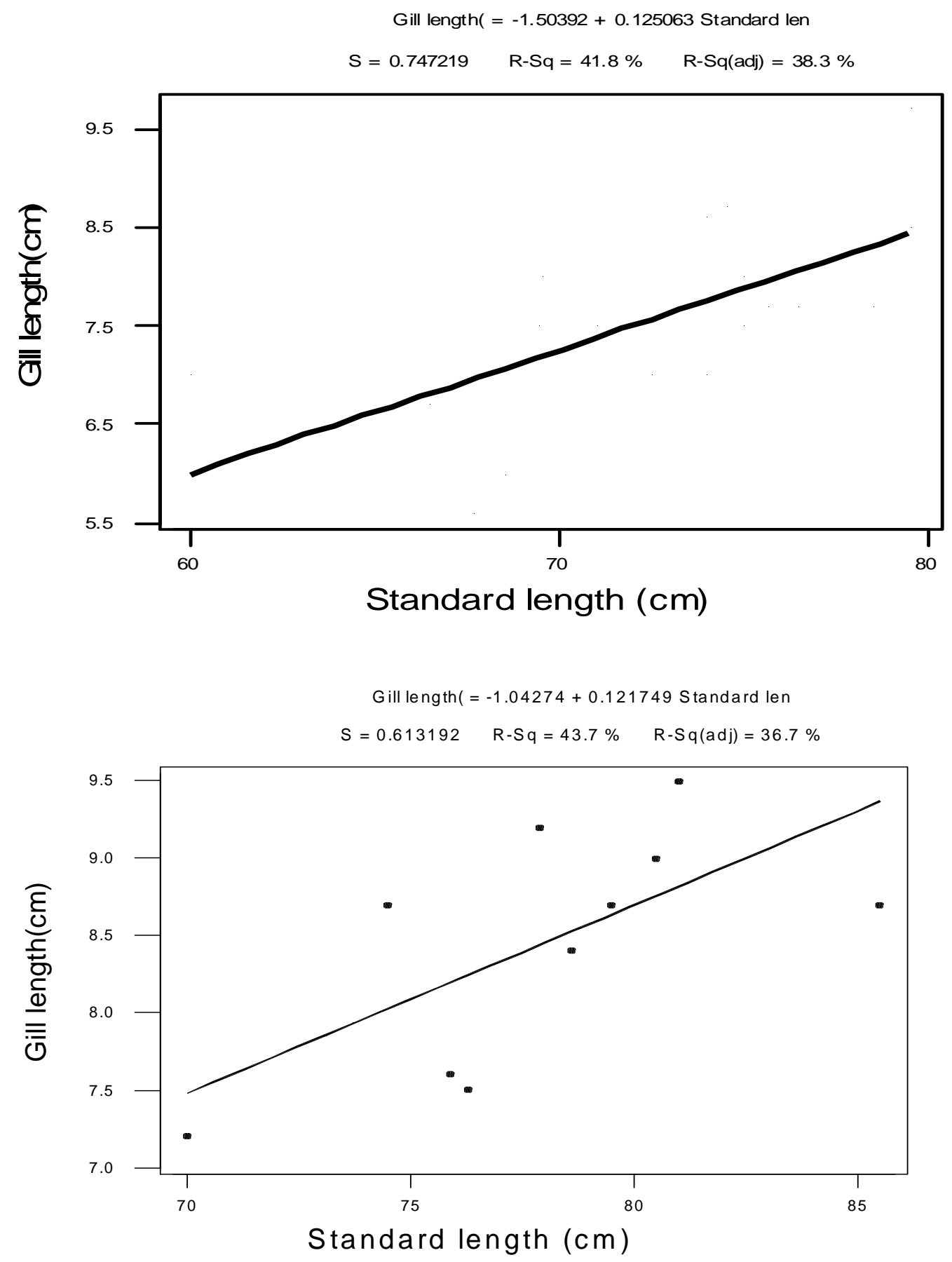

Figure 3a: standard length-gill length relation of infested (top) and non-infested (bottom) garfishes landed at Elmina harbour. 

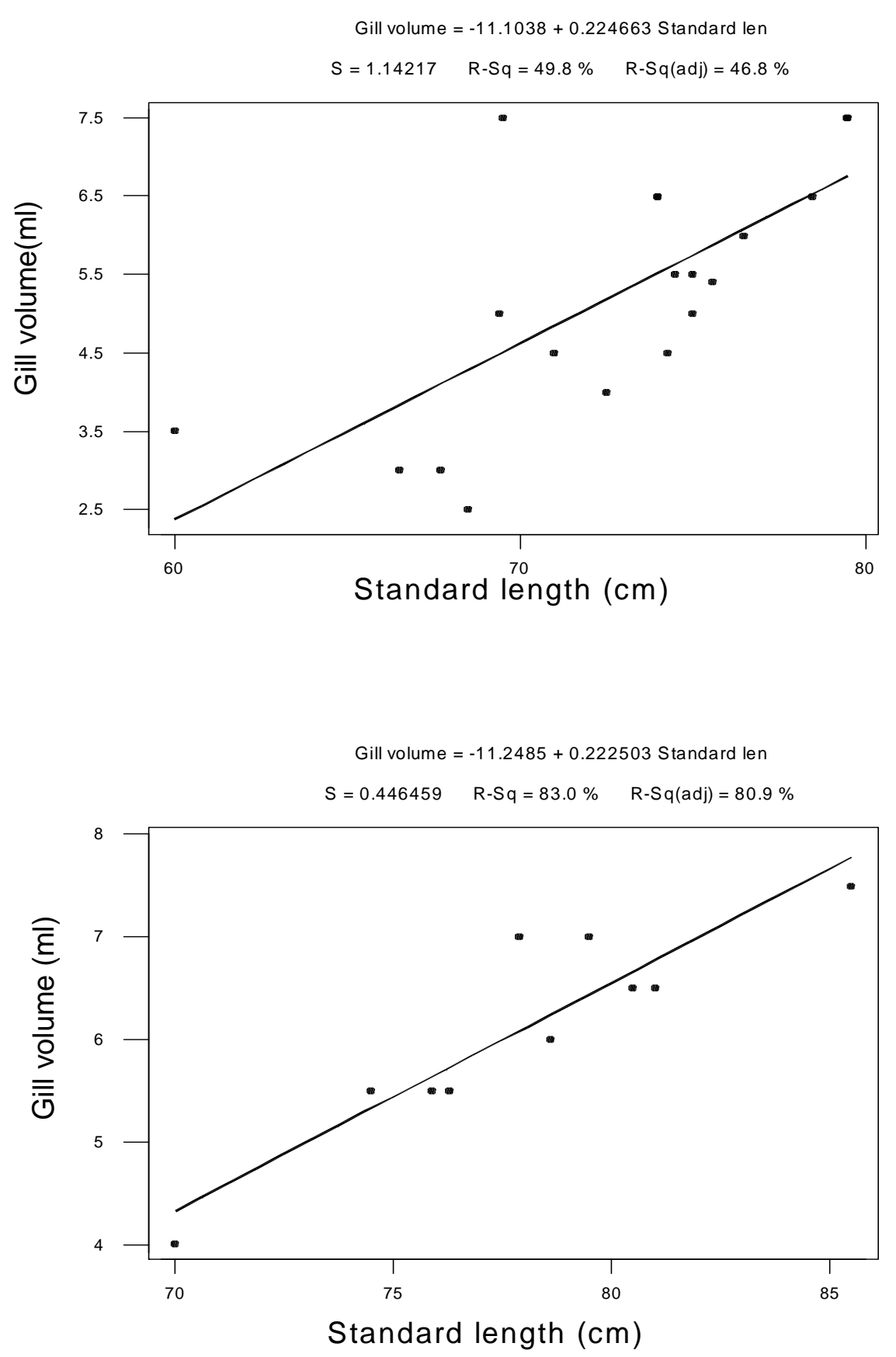

Figure 3b: Standard length-gill volume relation of infested (top) and non-infested (bottom) garfishes landed at Elmina harbour. 
Table 1a: Standard length frequency distribution of infested and non-infested garfishes landed at the Elmina harbor.

\begin{tabular}{lcc}
\hline $\begin{array}{l}\text { Standard length } \\
(\mathbf{c m})\end{array}$ & Infested garfishes & Non-infested garfishe \\
\hline $60.0-64.9$ & $16(5.4)^{*}$ & $4(1.4)$ \\
$65.0-69.9$ & $29(9.8)$ & $6(2.0)$ \\
$70.0-74.9$ & $54(18.2)$ & $27(9.1)$ \\
$75.0-79.9$ & $63(21.3)$ & $34(11.5)$ \\
$80.0-84.9$ & $10(3.4)$ & $19(6.4)$ \\
$85.0-89.9$ & $18(6.1)$ & $16(5.4)$ \\
& & $\mathbf{1 0 6}(\mathbf{3 5 . 8 1})$ \\
Total & $\mathbf{1 9 0}(\mathbf{6 4 . 1 9})$ & \\
\hline Mean $=74.45 \pm 6.58 \mathrm{~cm})$ & Mean $=77.45 \pm 6.36 \mathrm{~cm}$ \\
$*$ Figures in parentheses are percentages &
\end{tabular}

Table 1b: Breadth frequency distribution of infested and non-infested garfishes Landed at the Elmina harbour.

\begin{tabular}{lcc}
\hline Breadth $(\mathbf{c m})$ & Infested garfishes & Non-infested garfishes \\
\hline $5.0-5.9$ & $17(5.7)^{*}$ & $11(3.7)$ \\
$6.0-6.9$ & $91(31.4)$ & $39(13.2)$ \\
$7.7-7.9$ & $53(17.9)$ & $35(11.8)$ \\
$8.0-8.9$ & $29(9.8)$ & $20(6.8)$ \\
$9.0-9.9$ & $0(0.0)$ & $1(0.3)$ \\
Total & $\mathbf{1 9 0}(\mathbf{6 4 . 1 9})$ & $\mathbf{1 0 6}(\mathbf{3 5 . 8 1})$ \\
\hline \multicolumn{2}{l}{ Mean $=6.94 \mathrm{~cm}( \pm 0.86$ S.E $) ;$ Mean $=7.08 \mathrm{~cm}( \pm 0.94$ S.E $) ;$ S.E $=$ Standard error } \\
*Figures in parentheses are percentages
\end{tabular}

Table 2a: Sex ratio of infested garfishes landed at the Elmina harbour (2006, 2007; 2008).

\begin{tabular}{lccccc}
\hline Sample size & $\begin{array}{c}\text { No. of } \\
\text { Infested } \\
\text { Males }\end{array}$ & $\begin{array}{c}\text { No. of } \\
\text { Infested } \\
\text { females }\end{array}$ & $\begin{array}{c}\text { Sex ratio of } \\
\text { infested }\end{array}$ & $\begin{array}{c}\text { Chi- } \\
\text { square } \\
\text { value }\left(\boldsymbol{\chi}^{\mathbf{2}}\right)\end{array}$ & Inference \\
\hline 16 & 7 & 9 & $\mathbf{1 : 1 . 2 9}$ & $\mathbf{0 . 2 5 0}$ & Insig. \\
29 & 13 & 16 & $\mathbf{1 : 1 . 2 3}$ & $\mathbf{0 . 3 2 0}$ & Not sig. \\
54 & 21 & 23 & $\mathbf{1 : 1 . 1 0}$ & $\mathbf{2 . 6 6 7}$ & Not sig. \\
63 & 29 & 34 & $\mathbf{1 : 1 . 1 7}$ & $\mathbf{0 . 3 9 7}$ & Not sig. \\
10 & 4 & 6 & $\mathbf{1 : 1 . 5 0}$ & $\mathbf{0 . 4 0 0}$ & Not sig. \\
18 & 15 & 3 & $\mathbf{1 . 2 0 :} \mathbf{1}$ & $\mathbf{8 . 0 0 0}$ & Sig. \\
$\mathbf{1 9 0}$ & $\mathbf{8 9}$ & $\mathbf{9 1}$ & $\mathbf{1 : 1 . 0 2}$ & $\mathbf{0 . 7 5 8}$ & Not sig. \\
\hline
\end{tabular}


E.A. OBODAI et al. / Int. J. Biol. Chem. Sci. 5(1): 123-133, 2011

Table 2b: Sex ratio of non-infested garfishes landed at the Elmina harbour (2006, 2007; 2008)

\begin{tabular}{lccccc}
\hline Sample size & $\begin{array}{c}\text { No. of Non-infested } \\
\text { males }\end{array}$ & $\begin{array}{c}\text { No. of Non-infested } \\
\text { Females }\end{array}$ & $\begin{array}{c}\text { Sex ratio of } \\
\text { non-infested }\end{array}$ & $\begin{array}{c}\text { Chi-square } \\
\text { Value }\left(\boldsymbol{\chi}^{\mathbf{2}}\right)\end{array}$ & Inference \\
\hline 4 & 1 & 3 & $\mathbf{1 : 3}$ & $\mathbf{1 . 0 0 0}$ & Not sig. \\
6 & $\mathbf{2}$ & 4 & $\mathbf{1 : 2}$ & $\mathbf{0 . 6 6 7}$ & Not sig. \\
27 & 11 & 16 & $\mathbf{1 : 1 . 4 6}$ & $\mathbf{0 . 9 2 5}$ & Not sig. \\
34 & 15 & 19 & $\mathbf{1 : 1 . 2 7}$ & $\mathbf{0 . 4 7 0}$ & Not sig. \\
19 & 9 & 10 & $\mathbf{1 : 1 . 1 1}$ & $\mathbf{0 . 0 5 3}$ & Not sig. \\
16 & 7 & 9 & $\mathbf{1 : 1 . 2 9}$ & $\mathbf{0 . 2 5 0}$ & Not sig. \\
$\mathbf{1 0 6}$ & $\mathbf{4 5}$ & $\mathbf{6 1}$ & $\mathbf{1 : 1 . 3 6}$ & $\mathbf{2 . 4 1 5}$ & Not sig. \\
\hline
\end{tabular}

Table 3: Nutritional content of garfish landed at Elmina harbour

\begin{tabular}{lcc}
\hline Components & Infested garfish & Non-infested garfish \\
\hline Moisture & 76.1 & 76.8 \\
Protein & 19.8 & 20.8 \\
Fat & 0.8 & 0.9 \\
Carbohydrates(glycogen) & 78.1 & 77.4 \\
Ash & 1.3 & 1.4 \\
\hline
\end{tabular}




\section{DISCUSSION}

The current study covers copepod infestation of the buccal cavity and its effect on some selected body parameters as well as sex ratio and biochemical component of the garfish. The high level of copepod infestation indicates the rather high prevalence of the phenomenon in the species and suggests that care must be taken when processing the fish for meals. The head should be completely chopped off or the copepods selectively removed from the mouth, to avoid eating the decapods. In spite of the high infestation, the differences in size (both standard length and body depth) between the infested and the noninfested were not significant. But it must be stated that these parameters were slightly larger for the non-infested than the infested.

The sex ratio of the garfish indicates that males are fewer than females. This corroborates the finding by Hatch (2003) who reported that males rarely attain 11 years, but females live up to 22 years. Thus the current observation could be attributed to the difference in longevity between the two sexes. It would, however, appear that infestation draws the sex ratio nearer to the optimal sex ratio of 1:1, as reported by Abban et al. (1994) for fish species under stress.

The condition index of the garfish suggests that the fish is in good condition throughout the season of its capture and that copepod infestation has no effect on the garfish.

Similarly, copepod infestation does not produce any significant effect on standard length - gill length/gill volume relation, which indicates that longer fishes tend to have longer gills and larger gill volumes. The slightly longer gill length and larger gill volume of the non-infested gar fishes agrees with the results of Hislop and Shanks (1979) and Margolis et al. (1982) that gill length and volume of noninfested garfishes are longer/larger than those of the infested ones.

Thus the exact role (parasitic or nonparasitic) of the copepod found in the mouth of the garfish is not known. However, Mann (1998) reported that the copepod infestation caused a reduction in the fat content of the garfish from $3.8 \%$ to $1.6 \%$.

According to FAO (1986), there are five main constituents of fish that attract compositional analysis. These are moisture, protein, fat, ash and carbohydrate (glycogen), which is usually obtained by subtraction (A.O.A.C, 1990). The values obtained for constituents in the current study fall within the range reported by some authors. Sidwel (1981) reported a range of 18 to $25 \%$ protein for seafood including fish Tenny et al. (1984) quoted moisture content of sea food to be between 70 and $80 \%$, while Ogunlade et al. (2005) reported moisture content of between 70 and $75 \%$ for finfish. The lower protein content of the infested garfishes suggests a negative effect of the copepod infestation. However, this should be interpreted with caution as there is no significant difference in the protein content between the infested and the non-infested. The high protein content of the garfishes (infested and non-infested) indicates that the species could be recommended for people with proteindeficiency disorders (Warlaw et al., 1994). Conversely, the generally low fat content of the garfish (infested or non-infested) suggests that the species could be recommended to people with obesity problem. The lower fat content of the infested specimens agrees with Mann's (1998) report referred to earlier.

Carbohydrate is the main source of energy for muscular activity such as swimming in the fish. Copepod infestation could render the fish less active, and be less efficient at utilizing this source of energy. The non-infested fish, on the other hand, exploit carbohydrate for swimming and other forms of stress and struggle, resulting in higher metabolic rate which lowered their carbohydrate content (Pyke, 1986). This author reported rapid decline in fish carbohydrate content during stress and struggle. Other authors have also associated lower carbohydrate content of estuarine animals with higher metabolic rate (McLusky, 1989; Yankson et al., 1994). The moderately high ash content suggests high mineral 
content of the garfish. This enhances its nutritional value as a source of minerals for people who lack these in their diets.

It is concluded that garfish had a high rate of copepod infestation, which did not have a discernible effect on condition index, sex ratio, standard - gill length/gill volume relationship and the biochemical composition of the fish. However, the fish could be recommended as good source of protein for the malnourished and low source of fat for obese people.

It is recommended that further research be undertaken to unravel the mirth surrounding copepod infestation of the garfish.

\section{REFERENCES}

Abban EK, Ofori-Danson PK, Biney CK. 1994. Fisheries and Aquaculture Development of Impoundments in West Gonja District, Northern Ghana. IAB Tech. Rep. No. B; 75p.

A.O.A.C. 1990. Official Methods Analysis $\left(15^{\text {th }}\right.$ edn). Association of Analytical Chemists: Washington D.C.

Bagenal T. 1978. Methods for Assessment of Fish Production in Fresh Waters. Blackwell Scientific Publications: Oxford, London; 365p.

F.A.O. 1986. Manuals of Food Quality Control, food analysis; general technique, Additives contaminants and composition. Food Nutrition Paper, 203-229.

Hatch H. 2003. Journal of Fish Biology. Academic Press: London, USA.

Hislop JRG, Shanks AM. 1979. Recent investigations on the Reproductive Biology of the Haddock, Malanogrammus aeglafinus, of the Northern Northsea and the effects of fecundity of infection with copepod parasites Lernaecera brachialis. ICES Journal of Marine Science, 39: 244-251.
Kennedy D, Williams H. 1989. The Biology of Organisms. Wiley: New York; 374p.

Margolis L, Esch, GW, Holmes AM, Holmes JC, Kurtis AM, Schad GA. 1982. The use of ecological terms in parasitology. Journal of Parasitlology, 68: 131-133.

McLusky DS. 1989. The Estuarine Ecosystem ( $2^{\text {nd }}$ edn). Blackie and Son Ltd: Glasgow and London; 215.

Ogunlade I, Olaofe O, Fadare T. 2005. Chemical composition amino acids and functional properties of selected sea foods. Journal of Food, Agriculture and Environment, 3(2): 130-133.

Paulson R, Hatch F. 2001. Evolution of Marine Life. Penguin Books: Harmonds Worth; 402p.

Pyke M. 1986. Success in Nutrition. John Murray Ltd.: London.

Sidwel VD. 1981. Chemical and Nutritional Composition of Finfishes, Whales Crustaceans, Mollusks and their Products. Technical Memorandum, Nutritional Oceanic and administration, Nutritional Marine Fisheries Services. U.S. Department of Commerce: Washington D.C.; 43p.

Tenny FM, Ganhlitz EIASA, Houle CR. 1984. Mineral composition of edible muscle tissueof seven species of fish from the Northeast Pacific. Journal of food, Agriculture and Food Chemistry, 32: 852- 855.

Warlaw GM, Inseel PM, Seyler MF. 1994. Contemporary Nutrition Issues and Insights ( $2^{\text {nd }}$ edn). Clarida Co.: USA.

Yankson K, Plahar WA, Obodai EA. 1994. Seasonal changes in biochemical composition of the mangrove oyster, Crassostrea tulipa (Lamarck) occurring in two coastal water bodies in Ghana. Ghana J. Science, 31-36: 37-43. 